ISSN 1392-3196 / e-ISSN 2335-8947

Zemdirbyste-Agriculture, vol. 102, No. 4 (2015), p. 363-370

DOI $10.13080 /$ z-a.2015.102.046

\title{
The interaction between maize and weeds under the conditions of long-term reduced tillage
}

\author{
Dovilè AVIŽIENYTE் ${ }^{1,2}$, Kęstutis ROMANECKAS ${ }^{2}$, Aida ADAMAVIČIENÉ2 \\ Egidijus ŠARAUSKIS ${ }^{3}$, Elena JAKIENE ${ }^{4}$ \\ ${ }^{1}$ Rumokai Experimental Station, Lithuanian Research Centre for Agriculture and Forestry \\ Rumokai, Vilkaviškis distr., Lithuania \\ ${ }^{2}$ Institute of Agroecosystems and Soil Sciences, Aleksandras Stulginskis University \\ Studentų 11, Akademija, Kaunas distr., Lithuania \\ E-mail: kestas.romaneckas@asu.lt \\ ${ }^{3}$ Institute of Agricultural Engineering and Safety, Aleksandras Stulginskis University \\ Studentu 15, Akademija, Kaunas distr., Lithuania \\ ${ }^{4}$ Institute of Agriculture and Food Science, Aleksandras Stulginskis University \\ Studentų 11, Akademija, Kaunas distr., Lithuania
}

\begin{abstract}
One of the most common problems in long-term reduced or no-tillage practices is increased weed infestation. In this study, as no clear conclusions for Southern Baltic Region transitional maritime-continental climate and soil conditions have been reached to date, we investigated the interactions between maize and weeds in such technologies with low herbicide application levels. Toward this aim, a long-term field experiment was initiated at the Experimental Station of Aleksandras Stulginskis University, Kaunas district, Lithuania $\left(54^{\circ} 52^{\prime}\right.$ N, $23^{\circ} 49^{\prime}$ E) in 1988. The soil was ploughed to a depth of $22-25 \mathrm{~cm}$ (control) and $12-15 \mathrm{~cm}$, cultivated to a depth of $25-30$ and $10-12 \mathrm{~cm}$ or no-tilled.

In deep-cultivated, shallow-cultivated and no-tilled plots, the residues covered 5.9, 5.7 and 13.2 times higher area of the soil surface than that in the control. The reduced primary and no-tillage conditions typically showed irradiance increases at the $1 / 4,1 / 2$ and $3 / 4$ altitudes of maize crop. Besides, more weed seeds were found in the upper $0-15 \mathrm{~cm}$ layer $(60 \%)$ than in the deeper $(15-25 \mathrm{~cm})$ layer $(40 \%)$. In the deep and shallow-cultivated plots, there were 2 and 3 times more perennial weeds than in the conventionally ploughed. At the end of the maize (Zea mays L.) vegetation, in the shallow-ploughed, deep and shallow-cultivated or no-tilled plots, there was 46, 40, 30 and $16 \%$ greater weed stand density, whereas the dry mass of weeds decreased by $30,22,36$ and $17 \%$, respectively.

Weed infestation in the short season maize primarily depended on the soil coverage with pre-crop residues, the maize stand density, the maize canopy height and the solar radiation level over the soil surface.
\end{abstract}

Key words: crop stand irradiance, residue coverage, weed biomass, weed seed bank, weed stand density, Zea mays.

\section{Introduction}

Reduced tillage maintains at least $30 \%$ residue coverage on the soil surface (Morris et al., 2010). Residue coverage influences lower moisture evapotranspiration, higher soil water content and soil structural stability, more effective prevention of soil erosion (Romaneckas et al., 2013) and higher economic effectiveness (Sarauskis et al., 2013). However, reduced tillage leads to different weed seed bank distribution or size in the soil and lower herbicide effectiveness (Chauhan et al., 2012; Nichols et al., 2015) and other indices. How much do different tillage systems influence the weed infestation of crops? Firstly, weed stand density depends on the competition ability of the crop. Cereals generally have higher competitiveness than beet, maize or potato. For example, Vakali et al. (2011) showed that in deeply cultivated plots, weed shoot biomass in the barley crop was $65-88 \%$ higher than that in ploughed plots, but in rye no clear influence was found. Ozpinar and Ozpinar (2011) established that shallow soil rototilling (compared with mouldboard ploughing) increased the total weed density by $72 \%$ and $58 \%$ in maize and vetch crops, while the differences in wheat were small. Similar results were found by Mashingaidze et al. (2012). In maize, no-tillage resulted in up to 20 times more weed infestation than ploughing (Gruber et al., 2012). The spread of perennial weeds was typically more evident (Carter et al., 2002). However, Streit et al. (2002) showed that for no-tillage technologies without herbicides, the weed density was lower than that in conventional or minimum tillage. In technologies with herbicides, Ishaya et al. (2008) found converse results. 
Different soil tillage intensities may slightly change the diversity of weed species in crops. In experiment by Plaza et al. (2011), in minimally tilled plots there were more weed species than in not tilled or traditionally ploughed plots. In Carter and Ivany (2006) experiment, the weed species diversity was slightly lower in ploughed soil than in shallowly or not tilled. In addition, high weed infestation resulted in substantial reductions in maize yield (Abdin et al., 2000).

Worldwide experiments on reduced soil tillage have been well documented, but investigations with maize crop (especially using the no-tillage system) are quite new for short vegetative season in subarctic climate conditions. Therefore, the objective of our investigations was to establish the influence of long-term reduced primary soil tillage on maize crop weediness and to find the main factors of weed-maize interaction.

\section{Material and methods}

Site and experiment description. A long-term field experiment was initiated at the Experimental Station of Aleksandras Stulginskis University, Kaunas district, Lithuania $\left(54^{\circ} 52^{\prime} \mathrm{N}, 23^{\circ} 49^{\prime} \mathrm{E}\right)$ in 1988. In 2001, the design of the experiment was slightly modified, and a no-tillage treatment was included. The data for the third rotation (2010-2012) are presented in this study.

The climate of Lithuania is transitional maritime-continental. The annual precipitation rate is $490-720 \mathrm{~mm}$, with an average annual temperature of $6.2^{\circ} \mathrm{C}$. The coldest month is January, and the warmest and most humid month is July. The soil of the experimental site is Endohypogleyic-Eutric Planosol (PLe-gln-w), with a texture classified as silty light loam (46\% sand, $42 \%$ silt, $12 \%$ clay). The soil is moderate in humus and rich in calcium. Other soil chemical properties are listed in Table 1. The variations in these indices depended on the long-term tillage impact (unpublished data).

Table 1. Soil chemical properties

\begin{tabular}{cccc}
\hline Parameter & $\begin{array}{c}\text { Soil layer } \\
\mathrm{cm}\end{array}$ & 2010 & 2012 \\
\hline \multirow{2}{*}{$\mathrm{pH}_{\mathrm{KCl}}$} & $0-15$ & $6.7-7.0$ & $6.7-6.9$ \\
& $15-25$ & $6.7-7.0$ & $6.8-6.9$ \\
\hline \multirow{2}{*}{$\mathrm{P}_{2} \mathrm{O}_{5} \mathrm{mg} \mathrm{kg}^{-1}$} & $0-15$ & $147.2-205.3$ & $141.0-201.3$ \\
\hline \multirow{2}{*}{$\mathrm{K}_{2} \mathrm{O} \mathrm{mg} \mathrm{kg}$} & $15-25$ & $111.2-182.8$ & $113.1-155.6$ \\
\hline
\end{tabular}

The primary tillage methods investigated included 1) control treatment - conventional ploughing (CP) to a depth of $22-25 \mathrm{~cm}$ with a mouldboard plough, 2) shallow ploughing (SP) to a depth of $12-15 \mathrm{~cm}$ with the same plough, 3 ) deep cultivation (DC) to a depth of 25-30 cm with a chisel cultivator, 4) shallow cultivation (SC) to a depth of 10-12 cm with a disc harrow and 5) notillage (NT) (direct sowing). The number of replications was four, and the plot distribution was randomised. The initial size of each plot was $126 \mathrm{~m}^{2}(14 \times 9 \mathrm{~m})$, and the size of the record plot was $70 \mathrm{~m}^{2}(10 \times 7 \mathrm{~m})$. The crop rotation in the experiment comprised spring oilseed rape, winter wheat, maize (sugar beet up to 2007) and spring barley. The agricultural practices used in the experiment are presented in Table 2.

After crop harvesting, all experimental plots (except the NT treatment) were loosened by a disc harrow Väderstad Carrier 300 (Väderstad-Verken AB, Sweden) to a depth of $12-15 \mathrm{~cm}$. A tractor John Deere 6620 (Deere \& Company, USA) was used in the experiment. Primary tillage was performed in October. The soil was ploughed by a plough Gamega PP-3-43 (Gamega Ltd., Lithuania) with semi-helical mouldboards. Deep cultivation was carried out with a chisel cultivator. The SC plots were additionally cultivated by a disc harrow. The NT plots were not tilled. In spring, after the soil had reached physical maturity, it was shallow-cultivated by a cultivator Laumetris KLG-3.6 (Laumetris Ltd., Lithuania) to a depth of 2-3 cm (except for the NT plots). A complex fertiliser was then spread by a fertiliser spreader Amazone-ZA-M-1201 (AMAZONEN-Werke H. Dreyer $\mathrm{GmbH} \&$ Co. KG, Germany). Pre-sowing soil tillage was performed after the fertiliser had been spread with the same cultivator to a 5-6 cm depth. We used a sowing machine Väderstad Rapid 300C Super XL (Väderstad-Verken AB, Sweden). The sowing rate was approximately 100 thousand seeds per hectare. Sowing was performed by a continuous band, wide-row method with $50-\mathrm{cm}$-wide inter-rows between bands and $12.5-\mathrm{cm}$ wide inter-rows between the rows. Maize hybrids (Pioneer Hi-Bred Ltd., Canada) earlier maturity (FAO number less than 180) were used. Herbicides were sprayed by a sprayer Amazone UF-901 (AMAZONEN-Werke). The maize was harvested at the end of September, when the kernels contained more than $60 \%$ dry matter.

Methods. The coverage of plant residues (winter wheat straw) was established visually after maize (Zea mays L.) sowing. For visual assessment, we used a 10-m-long metal band, which was placed perpendicular to the sowing direction at two sites in each plot diagonal to the sowing rows. The points of contact with the winter wheat straw were determined every $10 \mathrm{~cm}$ (total of 100 spots).

The soil chemical properties were determined after maize sowing at $0-15$ and $15-25 \mathrm{~cm}$ depths at 20 sites in a record plot in 2010 and 2012. Composite soil samples were formed. The samples were collected with a sampling auger. The soil $\mathrm{pH}_{\mathrm{KCl}}$ was established by the potentiometric method in $1 \mathrm{~N} \mathrm{KCl}$ extract (ISO 10390:2005); while the available phosphorus content was determined by the calcium acetate-lactate (CAL) method using a spectrometer and the available potassium content - by the same method using a flame photometer.

The maize stand density was assessed at 10 sites in a record plot in a 1-m row. The maize density was evaluated 25 days after the beginning of emergence.

The photosynthetic active radiation (PAR) interception in the maize crops was estimated at $\mathrm{BBCH}$ 71-75 stage. The PAR was measured with an HD 9021 RAD/PAR radiometer (PAR E m², 400-700 nm wavelengths). The measurements were recorded at different heights of the maize canopy; namely, at the soil surface and at $1 / 4,1 / 2$ and $3 / 4$ above the crop at five sites in the record plot. 
Table 2. Technological operations and timing

\begin{tabular}{lccc}
\hline \multicolumn{1}{c}{ Technological operation } & \multicolumn{1}{c}{ Date } \\
\cline { 2 - 4 } & $2009-2010$ & $2010-2011$ & $2011-2012$ \\
\hline Stubble loosening (except NT plots) & 02092009 & 30082010 & 02092011 \\
Glyphosate (herbicide Roundup) application & 05092009 & 30082010 & 03052011 \\
$\left(360 \mathrm{~g} \mathrm{~L}^{-1}, 4 \mathrm{~L} \mathrm{ha}^{-1}\right)$ in NT plots only & 05102009 & 08182010 & 17102011 \\
Primary tillage & 23042010 & 23042011 & 30042012 \\
Surface tillage & 26042010 & 03052011 & 03052012 \\
Complex fertilisation NPK 16:16:16 (250-300 $\left.\mathrm{kg} \mathrm{ha}^{-1}\right)$ & 27042010 & 03052011 & 03052012 \\
Pre-sowing soil tillage & 01052010 & 03052011 & 03052012 \\
Sowing & & & 31052012 \\
Foramsulfuron (herbicide Maister) application & 07062010 & 27052011 & - \\
$\left(22.5 \mathrm{~g} \mathrm{~L}^{-1}, 1.5 \mathrm{~L} \mathrm{ha}^{1}\right)$ before maize 6-leaf development & 28062010 & 27052011 & 25092012 \\
Additional fertilisation with ammonium nitrate $\left(\mathrm{N}_{68}\right) 180 \mathrm{~kg} \mathrm{ha}^{-1}$ & 14092010 & 26092011 & \\
Harvest & & & \\
\hline
\end{tabular}

The weed seed bank in the soil was determined at $0-15$ and $15-25 \mathrm{~cm}$ depths after primary soil tillage at 20 sites in a record plot in 2010 and 2012. The samples were collected with an auger, and a composite sample (per each plot of the experiment) was formed. Samples of $100 \mathrm{~g}$ of air-dried soil were placed on sieves with a $0.25-\mathrm{mm}$ mesh diameter and washed with running water until small soil particles washed out. Weed seeds and the remaining mineral soil fractions were separated from the organic soil fraction using a saturated salt (or potash) solution.

The maize crop weed incidence was assessed by identifying the weed species composition and weed stand density at the beginning of maize vegetation during intensive weed growth. The air-dried weed mass was determined at the end of maize vegetation. The weed incidence was assessed at 10 points in a record plot within a $0.06-\mathrm{m}^{2}$ area. The measurements were converted to the number of weeds per $\mathrm{m}^{2}$ and the air dry mass of weeds per $\mathrm{m}^{2}$. The weeds were pulled out and dried to an air-dry mass, and their composition was analysed. The data were not transformed.

The data from the experiment were statistically analysed using confidence tests with a one-way analysis of variance $(A N O V A)$. The treatment effect was tested using the $P$-test. The correlation analysis for the research data was conducted using software Stat and Sigma Plot. In the case of a significant difference between the specific treatment and the control (reference) treatment, the probability level was designated in the following way: * - differences significant at the $95 \%$ probability level or ** - differences significant at the $99 \%$ probability level.

Weather conditions. The meteorological conditions during the 2010-2012 maize growing seasons are highlighted in Table 3. Data from the Kaunas Meteorological Station are presented.

Table 3. Average air temperatures and rainfall during maize vegetation

\begin{tabular}{|c|c|c|c|c|c|c|c|}
\hline Parameter & April & May & June & July & August & September & October \\
\hline \multicolumn{8}{|c|}{2010} \\
\hline Temperature ${ }^{\circ} \mathrm{C}$ & 7.4 & 13.7 & 16.5 & 21.8 & 19.7 & 12.0 & 4.8 \\
\hline Rainfall mm & 58.5 & 94.8 & 127.0 & 100.7 & 82.5 & 63.3 & 44.6 \\
\hline \multicolumn{8}{|c|}{2011} \\
\hline Temperature ${ }^{\circ} \mathrm{C}$ & 8.9 & 13.1 & 18.1 & 19.6 & 18.1 & 13.6 & 7.7 \\
\hline Rainfall mm & 25.2 & 46.9 & 82.7 & 144.0 & 152.4 & 73.9 & 21.6 \\
\hline \multicolumn{8}{|c|}{2012} \\
\hline Temperature ${ }^{\circ} \mathrm{C}$ & 7.7 & 13.7 & 15.3 & 19.4 & 17.1 & 13.3 & 7.6 \\
\hline Rainfall mm & 72.3 & 50.3 & 93.4 & 112.8 & 69.2 & 67.2 & 75.0 \\
\hline \multicolumn{8}{|c|}{ Long-term (32 yr) average } \\
\hline Temperature ${ }^{\circ} \mathrm{C}$ & 6.7 & 12.6 & 15.6 & 17.6 & 17.1 & 12.2 & 7.1 \\
\hline Rainfall mm & 38.1 & 47.2 & 66.7 & 83.0 & 73.2 & 53.8 & 54.7 \\
\hline
\end{tabular}

The maize development conditions in 2010 2012 were wet and primarily warmer than usual. In 2010, the precipitation rate was approximately 54\% higher than the 32-year average; in 2011 and 2012, it was $45 \%$ and $28 \%$ higher than the 32 -year average. Higher than usual precipitation rates during the growing season (May-September) slightly influenced the spread of weeds $(r=0.302-0.305)$. In most cases, the average air temperatures during maize growth were higher than usual. July was much warmer $\left(1.8-4.2^{\circ} \mathrm{C}\right)$ than the longterm average.

\section{Results and discussion}

Residue coverage and maize stand density. Crop residues on the soil surface suppress the infestation 
of weeds (Murungu et al., 2011; Chauhan et al., 2012). According to Gill et al. (1992), regression analysis showed that $20.4 \mathrm{~kg} \mathrm{ha}^{-1}$ of residue mulch can reduce weed biomass by $1.0 \mathrm{~kg} \mathrm{ha}^{-1}$. In our experiment, reducing the soil tillage intensity consecutively increased the soil surface coverage with pre-crop residues (Table 4).

Table 4. Soil surface coverage with pre-crop residues (winter wheat straw) and maize crop stand density at the emergence of vegetation

\begin{tabular}{lcccccc}
\hline \multirow{2}{*}{\multicolumn{1}{c}{ Soil tillage }} & \multicolumn{3}{c}{ Residue coverage \% } & \multicolumn{2}{c}{ Stand density, thousand ha ${ }^{-1}$} \\
\cline { 2 - 7 } & 2010 & 2011 & 2012 & 2010 & 2011 & 2012 \\
\hline Conventional ploughing (control) (CP) & 1.0 & 6.2 & 4.8 & 61.2 & 93.2 & 94.8 \\
Shallow ploughing (SP) & 2.5 & 3.0 & 15.2 & 49.2 & $84.8^{*}$ & 84.4 \\
Deep cultivation (DC) & $22.0^{* *}$ & 8.5 & $39.8^{* *}$ & 47.2 & 85.6 & 91.2 \\
Shallow cultivation (SC) & $17.5^{* *}$ & $17.2^{*}$ & $33.5^{* *}$ & 55.2 & $83.6^{*}$ & 88.0 \\
No-tillage (NT) & $70.3^{* *}$ & $20.5^{*}$ & $67.0^{* *}$ & 52.0 & 92.0 & 88.4 \\
\hline
\end{tabular}

* - significant differences from control treatment $(\mathrm{CP})$ at a $95 \%$ probability level $(p<0.05), * *-$ at a $99 \%$ probability level $(p<0.01)$

On average, after the sowing operation, there were 1.7 times more residues in the SP lots than in the control plots (CP). In the DC, SC and NT plots, the residues covered 5.9, 5.7 and 13.2 times significantly higher area of the soil surface, respectively.

Gul et al. (2009) found that denser maize crops increase the competition between maize and weeds. Similarly, an increase in maize plant density from 4 to 10 plants $\mathrm{m}^{-2}$ reduced the weed biomass by up to $50 \%$ (Tollenaar et al., 1994). In our experiment, only in 2011, 25 days after the beginning of seed emergence, stand differences were found (Table 4). In 2010 and 2012, the variation in stand density was similar and insignificant.

The correlation analysis of the experimental data showed a relationship between the number of annual and total weeds at the beginning of maize growth. There was also a relationship between the residue coverage after maize sowing ( $r=-0.694 * *$ and $-0.648^{* *}$, respectively) and the maize crop stand density at the beginning of vegetation ( $r=-0.926^{* *}$ and $-0.948^{* *}$, respectively).

Irradiance conditions in the maize stands. Maize and weeds compete for light conditions. Competition effects depend on the maize leaf area, leaf distribution, the height of the canopy, stand density and crop vegetation cover ratio (Uchino et al., 2012). Tajul et al. (2013) found that dense maize crops (stand density of 80,000 plants $\mathrm{ha}^{-1}$ ) in the conditions of optimal fertilisation rates $\left(180 \mathrm{~kg} \mathrm{ha}^{-1} \mathrm{~N}\right)$ had larger foliage and greater light absorption. However, the average maize plant height was higher in sparsely populated stands. In our experiment, the average height of maize plants in differently tilled or not tilled plots varied from 167.2 to $304.3 \mathrm{~cm}$ (Avižienyte et al., 2013). This strongly influenced the number of perennial weeds at the beginning of maize vegetation $\left(r=-0.652^{* *}\right)$ and the number of annual and total weeds at the end of maize growth (both $r=-0.723^{* *}$ ). At the time of the irradiation measurements, the variation of the maize stand density was low, and a stronger relationship between maize stand density and weed infestation was not found (Avižienyte et al., 2013). The reduced primary and no-tillage conditions typically showed irradiance increases at the $1 / 4,1 / 2$ and $3 / 4$ altitudes (Table 5).

In 2010 and 2012, in many cases the significantly highestirradiance was found in the weediestand lowermost

Table 5. Maize stand irradiance (photosynthetic active radiation, $\mathrm{PAR}^{1}$ ) conditions at the milk maturity $(\mathrm{BBCH} 71-75)$ stage

\begin{tabular}{|c|c|c|c|c|}
\hline \multirow{2}{*}{ Soil tillage } & \multicolumn{4}{|c|}{ Measuring altitude according to height of maize canopy } \\
\hline & over soil surface & $1 / 4$ & $1 / 2$ & $3 / 4$ \\
\hline \multicolumn{5}{|c|}{2010} \\
\hline Conventional ploughing (control) (CP) & 8.7 & 30.8 & 47.9 & 80.0 \\
\hline Shallow ploughing (SP) & 8.9 & 29.5 & 44.4 & 75.7 \\
\hline Deep cultivation (DC) & $12.8^{*}$ & 36.7 & $72.1^{* *}$ & $95.0 *$ \\
\hline Shallow cultivation (SC) & 10.5 & 30.2 & 52.5 & 84.9 \\
\hline No-tillage (NT) & 8.8 & 20.2 & 39.6 & $64.7 *$ \\
\hline \multicolumn{5}{|c|}{2011} \\
\hline Conventional ploughing (control) (CP) & 0.6 & 1.2 & 2.4 & 7.8 \\
\hline Shallow ploughing (SP) & 0.6 & 1.6 & 3.8 & 13.6 \\
\hline Deep cultivation (DC) & 0.7 & 2.0 & 4.2 & 22.0 \\
\hline Shallow cultivation (SC) & 0.7 & 2.0 & 4.6 & 20.8 \\
\hline No-tillage (NT) & 1.0 & 1.8 & 4.0 & 15.4 \\
\hline \multicolumn{5}{|c|}{2012} \\
\hline Conventional ploughing (control) (CP) & 12.3 & 18.3 & 31.8 & 72.5 \\
\hline Shallow ploughing (SP) & 16.1 & 22.9 & 42.9 & 78.0 \\
\hline Deep cultivation (DC) & $21.9 * *$ & $29.4^{* *}$ & $50.6^{* *}$ & 79.7 \\
\hline Shallow cultivation (SC) & 13.5 & $25.6^{*}$ & $48.6^{* *}$ & $86.4^{* *}$ \\
\hline No-tillage (NT) & 14.2 & 23.2 & 40.8 & 75.6 \\
\hline
\end{tabular}

Note. ${ }^{1}$ - data show the percentage expression of particular crop irradiance if the background radiation (over plants) equals $100 \%$. 
maize canopy plots of DC. In 2011, differences between treatments were insignificant. A relationship between the dry mass of total weeds and the PAR over the soil surface $\left(r=-0.581^{*}\right)$ was found.

Weed seed bank. The effectiveness of weed control mainly depends on the ability to destroy the existing seeds in the soil and to limit the access of new ones (Pilipavičius, 2007). In our experiment, different long-term primary soil tillage or no-till mostly had insignificant influence on the density of weed seed bank in the $0-15$ and $15-25 \mathrm{~cm}$ soil layers (Table 6). But the number of weed seeds in the upper $(0-5 \mathrm{~cm})$ soil layer in the CP plots was slightly higher (by $6 \%$ ) in comparison to that in the NT plots (data not presented).

Table 6. Weed seed bank distribution in the $0-15$ and $15-25 \mathrm{~cm}$ soil layers

\begin{tabular}{|c|c|c|c|c|}
\hline \multirow{3}{*}{ Soil tillage } & \multicolumn{4}{|c|}{ Number of seeds per $100 \mathrm{~g}$ of soil } \\
\hline & \multicolumn{2}{|c|}{2010} & \multicolumn{2}{|c|}{2012} \\
\hline & $0-15 \mathrm{~cm}$ & $15-25 \mathrm{~cm}$ & $0-15 \mathrm{~cm}$ & $15-25 \mathrm{~cm}$ \\
\hline Conventional ploughing (control) (CP) & 23 & 13 & 14 & 20 \\
\hline Shallow ploughing (SP) & 26 & 15 & 12 & 15 \\
\hline Deep cultivation (DC) & 27 & $28 *$ & 14 & 12 \\
\hline Shallow cultivation (SC) & 24 & 14 & 19 & 9 \\
\hline No-tillage (NT) & 20 & 8 & 17 & 11 \\
\hline
\end{tabular}

Tørresen et al. (2003) established that in conditions of reduced soil tillage, more weed seeds were found in the $0-10 \mathrm{~cm}$ depth soil layer than in the $10-20 \mathrm{~cm}$ layer. Similar observations were made by Nakamoto et al. (2006). Our results confirm these research findings. The upper $(0-15 \mathrm{~cm})$ layer contained $60 \%$ of the total seed number, while the lower $(15-25 \mathrm{~cm})$ layer contained $40 \%$. The dominant seeds originated from annual weeds: Chenopodium album L., Polygonum lapathifolia L., Echinochloa crus-galli L. and Sinapis arvensis L. Analysis of the experimental data showed a linear correlation between all (total) weed stand densities at the end of maize vegetation and the weed seed bank at the $0-15 \mathrm{~cm}$ depth $\left(r=0.895^{* *}\right)$. This relationship was weak at the $15-25 \mathrm{~cm}$ depth $(r=0.297)$.

Weed stands density and biomass. In our previous investigations (1989-2000) at the same experimental site, in the SP, DC and SC plots, the weed seeds and vegetative reproductive parts were distributed in the topsoil, which induced faster germination and regrowth as well as higher crop weediness (Stancevičius et al., 2002). In 2002-2006, after modification of the experiment (NT was included), the SP, DC and SC soil tillage technologies slightly increased weed infestation in sugar beet crops. In the NT plots, there was a higher number of annual $(32 \%)$ and total $(29 \%)$ weeds in comparison with the CP (control treatment) (Romaneckas et al., 2009). In Colbach et al. (2014) investigations, superficial tillage which left seeds closest to the soil surface resulted in the highest weed density. In our discussed investigation (2010-2012), at the beginning of maize vegetation, the reduced soil tillage increased the weed stand density. The number of perennial weeds varied more than did the number of annual weeds. On average, in the DC and SC plots there were 2 and 3 times more perennial weeds than in the control plots (Table 7). Despite that, the significance of results was rare.

Table 7. Weed stand density at the beginning of maize vegetation

\begin{tabular}{|c|c|c|c|}
\hline \multirow{2}{*}{ Soil tillage } & \multicolumn{3}{|c|}{ Weed groups number $\mathrm{m}^{-2}$} \\
\hline & annual & perennial & total \\
\hline \multicolumn{4}{|c|}{2010} \\
\hline Conventional ploughing (control) (CP) & 445.9 & 18.4 & 464.3 \\
\hline Shallow ploughing (SP) & 616.3 & 24.2 & $640.5^{*}$ \\
\hline Deep cultivation (DC) & 625.8 & 65.4 & $691.2 *$ \\
\hline Shallow cultivation (SC) & 520.8 & $83.8^{*}$ & 604.6 \\
\hline No-tillage (NT) & 515.5 & 35.9 & 551.4 \\
\hline \multicolumn{4}{|c|}{2011} \\
\hline Conventional ploughing (control) (CP) & 305.4 & 13.4 & 318.8 \\
\hline Shallow ploughing (SP) & 395.4 & 11.3 & 406.7 \\
\hline Deep cultivation (DC) & 314.6 & $40.0^{*}$ & 354.6 \\
\hline Shallow cultivation (SC) & 286.7 & $35.8^{*}$ & 322.5 \\
\hline No-tillage (NT) & 167.9 & 22.1 & 190.0 \\
\hline \multicolumn{4}{|c|}{2012} \\
\hline Conventional ploughing (control) (CP) & 188.4 & 47.9 & 236.3 \\
\hline Shallow ploughing (SP) & 193.7 & 115.0 & 308.7 \\
\hline Deep cultivation (DC) & 165.0 & 90.0 & 255.0 \\
\hline Shallow cultivation (SC) & 152.1 & $155.4 * *$ & 307.5 \\
\hline No-tillage (NT) & 107.1 & 82.9 & 190.1 \\
\hline
\end{tabular}


According to Trichard et al. (2013), the minimizing of soil disturbance may lead to changes in soil environmental properties and affect the composition of weed communities. In our experiment, we found 23 species of weeds in the experimental plots in 2010, 17 species in 2011 and 20 species in 2012. Chenopodium album L., Polygonum lapathifolia L. and Poa annua L. were the most widespread annual weeds, and Sonchus arvensis L., Cirsium arvense L. Scop. and Elytrigia repens L. Nevski were the most widespread perennials. The above-mentioned weed species accounted for 16,17 , $5,3,3$ and $8 \%$ of the total weed population therefore we did not find greater differences in the composition of weed communities. The correlation analysis of the 2010-2012 experimental data showed a partial relationship between the annual, perennial and total weed stand density at the beginning of maize vegetation and $0.25-1 \mathrm{~mm}$ size soil aggregate stability at the $0-15 \mathrm{~cm}$ depth $(r=0.631 *$, $-0.561^{*}$ and $\left.0.519 *\right)$. The soil aggregate stability varied from $32 \%$ to $50 \%$ (Romaneckas et al., 2015). Correlations between the weed stand density at the beginning of maize vegetation and other factors are mentioned above.

At the end of maize growth, we found similar tendencies to those at the beginning but due to unsatisfactory chemical weed control in maize stand and in its pre-crop, the number of weeds was still high. On average, in the SP, DC, SC and NT plots there were approximately 46, 40, 30 and $16 \%$ higher total weed stand densities than in the $\mathrm{CP}$ plots, respectively (Table 8). However, the dry mass of weeds increased by approximately $30,22,36$ and $17 \%$, respectively.

Table 8. Weed stand density and weed air-dry mass at the end of maize vegetation

\begin{tabular}{|c|c|c|c|c|c|c|}
\hline \multirow{3}{*}{ Soil tillage } & \multicolumn{6}{|c|}{ Weed groups } \\
\hline & \multicolumn{2}{|c|}{ annual } & \multicolumn{2}{|c|}{ perennial } & \multicolumn{2}{|c|}{ total } \\
\hline & $\begin{array}{c}\text { number } \\
\mathrm{m}^{-2}\end{array}$ & $\begin{array}{l}\text { mass } \\
\mathrm{g} \mathrm{m}^{-2}\end{array}$ & $\begin{array}{c}\text { number } \\
\mathrm{m}^{-2}\end{array}$ & $\begin{array}{l}\text { mass } \\
\mathrm{g} \mathrm{m}^{-2}\end{array}$ & $\begin{array}{c}\text { number } \\
\mathrm{m}^{-2}\end{array}$ & $\begin{array}{l}\text { mass } \\
\mathrm{g} \mathrm{m}^{-2}\end{array}$ \\
\hline \multicolumn{7}{|c|}{2010} \\
\hline Conventional ploughing (control) (CP) & 304.6 & 199.9 & 16.6 & 8.6 & 321.2 & 208.5 \\
\hline Shallow ploughing (SP) & $467.9 *$ & 283.2 & 15.4 & 11.4 & $483.3 *$ & $294.6 *$ \\
\hline Deep cultivation (DC) & 396.3 & $304.6^{*}$ & 42.5 & 31.7 & 438.8 & $336.3 * *$ \\
\hline Shallow cultivation (SC) & 367.9 & $317.7 *$ & 52.9 & 42.8 & 427.1 & $360.5 * *$ \\
\hline No-tillage (NT) & 272.1 & 260.2 & $75.8^{*}$ & $52.4 *$ & 347.9 & $312.6^{*}$ \\
\hline \multicolumn{7}{|c|}{2011} \\
\hline Conventional ploughing (control) (CP) & 40.8 & 93.0 & 6.7 & 16.7 & 47.5 & 109.7 \\
\hline Shallow ploughing (SP) & 48.3 & 119.0 & 18.3 & 66.9 & 66.6 & 185.9 \\
\hline Deep cultivation (DC) & 51.2 & 122.3 & 23.8 & 79.3 & 75.0 & $201.6^{*}$ \\
\hline Shallow cultivation (SC) & 49.6 & 103.9 & 12.1 & 13.3 & 61.7 & 117.2 \\
\hline No-tillage (NT) & 43.3 & 104.5 & 21.3 & 10.1 & 64.6 & 114.6 \\
\hline \multicolumn{7}{|c|}{2012} \\
\hline Conventional ploughing (control) (CP) & 109.9 & 193.7 & 33.4 & 70.3 & 143.3 & 264.0 \\
\hline Shallow ploughing (SP) & 150.0 & 165.2 & 47.1 & 111.1 & 197.1 & 276.3 \\
\hline Deep cultivation (DC) & 168.7 & 105.7 & 34.6 & 66.1 & 203.3 & 171.8 \\
\hline Shallow cultivation (SC) & 122.1 & 111.8 & 55.8 & $206.8 *$ & 177.9 & 318.6 \\
\hline No-tillage (NT) & 145.4 & 198.7 & 34.6 & 57.3 & 180.0 & 256.0 \\
\hline
\end{tabular}

Infestation of annual and total weeds at the end of maize growth partly depended on some soil chemical and physical properties and maize stand density (Table 9). In addition, there were correlations between the annualtotal weed number and the air-dry mass at the end of maize growth $\left(r=0.901^{* *}\right.$ and $0.668^{* *}$, respectively).
Likewise, there were correlations between the air-dry mass of perennial weeds at the end of maize vegetation and the soil $\mathrm{pH}$ at the $15-25 \mathrm{~cm}$ depth $(r$ $=-0.789 * *)$, the amount of soil $\mathrm{K}_{2} \mathrm{O}$ at the $15-25 \mathrm{~cm}$ depth $\left(r=0.723^{*}\right)$, a more than $1 \mathrm{~mm}$ size soil aggregate stability at the $0-15$ and $15-25 \mathrm{~cm}$ depths $\left(r=0.523^{*}\right.$

Table 9. The relationship (simple correlation coefficient $r$ ) between maize crop weediness, some soil physicochemical properties and maize stand density

\begin{tabular}{|c|c|c|c|c|c|}
\hline \multirow{3}{*}{\multicolumn{2}{|c|}{ Parameters $(x)$}} & \multicolumn{4}{|c|}{ Weed infestation $(y)$} \\
\hline & & \multicolumn{2}{|c|}{ annual weeds } & \multicolumn{2}{|c|}{ total weeds } \\
\hline & & number & air-dry mass & number & air-dry mass \\
\hline $\mathrm{P}_{2} \mathrm{O}_{5}(15-25 \mathrm{~cm})$ & & $0.692 *$ & $\mathrm{n}$ & $0.660^{*}$ & $\mathrm{n}$ \\
\hline $\mathrm{K}_{2} \mathrm{O}(15-25 \mathrm{~cm})$ & & $0.681^{*}$ & $\mathrm{n}$ & $0.659^{*}$ & $\mathrm{n}$ \\
\hline \multicolumn{6}{|l|}{ Penetration resistance at: } \\
\hline & $35 \mathrm{~cm}$ & $0.633^{*}$ & $0.635^{*}$ & $0.636^{* *}$ & $\mathrm{n}$ \\
\hline & $40 \mathrm{~cm}$ & $0.698 * *$ & $0.690 * *$ & $0.719 * *$ & $\mathrm{n}$ \\
\hline & $45 \mathrm{~cm}$ & $0.771 * *$ & $0.756^{* *}$ & $0.794 * *$ & $\mathrm{n}$ \\
\hline & $50 \mathrm{~cm}$ & $0.831 * *$ & $0.821 * *$ & $0.845^{* *}$ & $\mathrm{n}$ \\
\hline
\end{tabular}

Notes. * - at $P \leq 0.05, * *$ - at $P \leq 0.01, \mathrm{n}-$ weak or insignificant correlation. The primary data from soil penetration resistance and aggregate stability are presented in Romaneckas et al. (2015) article. 
and $0.515^{*}$ ) and a more than $0.25 \mathrm{~mm}$ size soil aggregate stability at the $0-15 \mathrm{~cm}$ depth $\left(r=0.515^{*}\right)$.

In our experiment, an increase in the weed stand density in the reduced tillage or no-tillage plots negatively influenced the maize crop biometrics (canopy height, cob length, number of kernels per row of cob) and productivity (biomass of canopy, grain yield, and 1000 kernel weight) parameters (Avižienytè et al., 2013).

\section{Conclusions}

1. At the beginning of maize vegetation, in the shallow ploughing (SP) plots, the pre-crop (winter wheat) residues covered 1.7 times more area than in the conventional ploughing (CP) (control). In the deep cultivation (DC), shallow cultivation (SC) and no-tillage (NT) plots, the residues covered, respectively, 5.9, 5.7 and 13.2 times more area of the soil surface. This affected the density of annual as well as total weeds $(r=-0.694 * *$ and $-0.648 * *)$.

2. In the reduced tillage and no-tillage plots, there was a slightly higher photosynthetic active radiation (PAR) level at the different measurement altitudes. The air-dry mass of total weeds depended on the PAR levels over the soil surface $(r=-0.581 *)$.

3 . In many cases, in the top $(0-15 \mathrm{~cm}$ depth) soil layer, the reduced tillage induced a higher concentration of weed seeds compared with the CP. Samples from the $15-25 \mathrm{~cm}$ depth showed converse results. Generally, in the conditions of reduced soil tillage or no-till, more weed seeds were found in the upper $0-15 \mathrm{~cm}$ layer $(60 \%)$ than in the deeper $15-25 \mathrm{~cm}$ layer $(40 \%)$.

4. Reduced tillage was associated with increased weed stand density. At the beginning of maize vegetation, the number of perennial weeds varied more than did the number of annual weeds. In the DC and SC plots, there were 2 and 3 times more perennial weeds than in the control treatment. At the end of maize vegetation in the SP, DC, SC and NT plots, there were 46, 40, 30 and $16 \%$ higher total weed stand densities than in the CP plots, whereas the dry mass of weeds was reduced by $30,22,36$ and $17 \%$, respectively.

Received 06052015 Accepted 11092015

\section{References}

Abdin O. A., Zhou X. M., Cloutier D., Coulman D. C., Faris M. A., Smith D. L. 2000. Cover crops and interrow tillage for weed control in short season maize (Zea mays). European Journal of Agronomy. 12: 93-102 http://dx.doi.org/10.1016/S1161-0301(99)00049-0

Avižienytė D., Romaneckas K., Pališkytė R., Bogužas V., Pilipavičius V., Šarauskis E., Adamavičienė A., Vaiciukevičius E. 2013. The impact of long-term reduced primary soil tillage on maize (Zea mays L.) productivity. Zemdirbyste-Agriculture, 100 (4): 377-382 http://dx.doi.org/10.13080/z-a.2013.100.048

Carter M. R., Ivany J. A. 2006. Weed seed bank composition under long-term tillage regimes on a fine sandy loam in Atlantic Canada. Soil and Tillage Research, 90: 26-38 http://dx.doi.org/10.1016/j.still.2005.08.002

Carter M. R., Sanderson J. B., Ivany J. A., White R. P. 2002. Influence of rotation and tillage on forage maize productivity, weed species, and soil quality of fine sandy loam in the cool-humid climate of Atlantic Canada. Soil and Tillage Research, 67: 85-98

http://dx.doi.org/10.1016/S0167-1987(02)00043-0
Chauhan B. S., Singh R. G., Mahajan G. 2012. Ecology and management of weeds under conservation agriculture: a review. Crop Protection, 38: 57-65

http://dx.doi.org/10.1016/j.cropro.2012.03.010

Colbach N., Busset H., Roger-Estrade J., Caneill J. 2014. Predictive modelling of weed seed movement in response to superficial tillage tools. Soil and Tillage Research, 138: $1-8$ http://dx.doi.org/10.1016/j.still.2013.12.002

Gill K. S., Arshad M. A., Chivunda B. K., Phiri B., Gumbo M. 1992. Influence of residue mulch, tillage and cultural practices on weed mass and corn yield from three field experiments. Soil and Tillage Research. 24: 211-223 http://dx.doi.org/10.1016/0167-1987(92)90088-S

Gruber S., Pekrun C., Möhring J., Claupein W. 2012. Longterm yield and weed response to conservation and stubble tillage in SW Germany. Soil and Tillage Research, 121: $49-56$ http://dx.doi.org/10.1016/j.still.2012.01.015

Gul B., Marwat K. B., Hassan G., Khan A., Hashim S., Khan I. A. 2009. Impact of tillage, plant population and mulches on biological yield of maize. Pakistan Journal of Botany, 41 (5): 2243-2249

Ishaya D. B., Tunku P., Kuchinda N. C. 2008. Evaluation of some weed control treatments for long season weed control in maize (Zea mays L.) under zero and minimum tillage at Samaru, in Nigeria. Crop Protection 27: 1047-1051 http://dx.doi.org/10.1016/j.cropro.2007.11.020

Mashingaidze N., Madakadze C., Twomlow S., Nyamangara J., Hove L. 2012. Crop yield and weed growth under conservation agriculture in semi-arid Zimbabwe. Soil and Tillage Research, 124: 102-110 http://dx.doi.org/10.1016/j.still.2012.05.008

Morris N. L., Miller P. C. H., Orson J. H., Froud-Williams R. J. 2010. The adoption of non-inversion tillage systems in the United Kingdom and the agronomic impact on soil, crops and environment - a review. Soil and Tillage Research, 108: $1-15$ http://dx.doi.org/10.1016/j.still.2010.03.004

Murungu F. S., Chiduza C., Muchaonyerwa P., Mnkeni P. N. S. 2011. Mulch effect on soil moisture and nitrogen, weed growth and irrigated maize productivity in warm-temperate climate of South Africa. Soil and Tillage Research, 112: $58-65$ http://dx.doi.org/10.1016/j.still.2010.11.005

Nakamoto T., Yamagishi J., Miura F. 2006. Effect of reduced tillage on weeds and soil organisms in winter wheat and summer maize cropping on Humic Andosols in Central Japan. Soil and Tillage Research, 85: 94-106 http://dx.doi.org/10.1016/j.still.2004.12.004

Nichols V., Verhulst N., Cox R., Govaerts B. 2015. Weed dynamics and conservation agriculture principles: a review. Field Crops Research. 183: 56-68 http://dx.doi.org/10.1016/j.fcr.2015.07.012

Ozpinar S., Ozpinar A. 2011. Influence of tillage and crop rotation systems on economy and weed density in a semi-arid region. Journal of Agricultural Science and Technology, 13: 769-784

Pilipavičius V. 2007. Spring barley and weed interaction in organic and conventional farming system. International scientific conference Organic farming 2007. Prague, Czech Republic, p. 107-110

Plaza E. H., Kozak M., Navarrete L., Gonzalez-Andujar J. L. 2011. Tillage system did not affect weed diversity in a 23year experiment in Mediterranean dryland. Agriculture, Ecosystems and Environment. 140: 102-105 http://dx.doi.org/10.1016/j.agee.2010.11.016

Romaneckas K., Romaneckiene R., Sarauskis E., Pilipavičius V., Sakalauskas A. 2009. The effect of conservation primary and zero tillage on soil bulk density, water content, sugar beet growth and weed infestation. Agronomy Research, 7 (1): $73-86$ 
Romaneckas K., Šarauskis E., Masilionytė L., Sakalauskas A. 2013. Impact of different tillage methods on silty loam Luvisol water content in sugar beet (Beta vulgaris L.) crop. Journal of Environmental Protection, 4: 219-225 http://dx.doi.org/10.4236/jep.2013.43026

Romaneckas K., Sarauskis E., Avižienytė D., Buragienè S., Arney D. 2015. The main physical properties of planosol in maize (Zea mays L.) cultivation under different longterm reduced tillage practices in the Baltic region. Journal of Integrative Agriculture, 14 (7): 1309-1320 http://dx.doi.org/10.1016/S2095-3119(14)60962-X

Sarauskis E., Masilionyte L., Kriauciuniene Z., Romaneckas K., Buragiene S. 2013. Evaluation of energy and environmental aspects of reduced tillage systems applied in maize cultivation. International Journal of Agricultural, Biosystems Science and Engineering, 7 (10): 641-643

Stancevičius A., Špokienè N., Jodaugienè D., Trečiokas K., Raudonius S. 2002. The influence of reduced soil tillage on crop weedness. Vagos, 55: 50-57 (in Lithuanian)

Streit B., Rieger S. B., Stamp P., Richner W. 2002. The effect of tillage intensity and time of herbicide application on weed communities and populations in maize in central Europe. Agriculture. Ecosystems and Environment. 92: 211-224 http://dx.doi.org/10.1016/S0167-8809(01)00307-3

Tajul M. I., Alam M. M., Hossain S. M. M., Naher K., Rafii M. Y., Latif M. A. 2013. Influence of plant population and nitrogen-fertilizer at various levels on growth and growth efficiency of maize. The Scientific World Journal, $2013(1)$

http://dx.doi.org/10.1155/2013/193018
Tollenaar M., Dibo A. A., Aguilara A., Weise S. F., Swanton C. J. 1994. Effect of crop density on weed interference in maize. Agronomy Journal, 86: 591-595 http://dx.doi.org/10.2134/ agronj1994.00021962008600040003x

Tørresen K. S., Skuterud R., Tandsæther H. J., Hagemo M. B. 2003. Long-term experiments with reduced tillage in spring cereals. I. Effects on weed flora, weed seedbank and grain yield. Crop Protection, 22: 185-200 http://dx.doi.org/10.1016/S0261-2194(02)00145-X

Trichard A., Alignier A., Chauvel B., Petit S. 2013. Identification of weed community traits response to conservation agriculture. Agriculture, Ecosystems and Environment, 179: $179-186$ http://dx.doi.org/10.1016/j.agee.2013.08.012

Uchino H., Iwama K., Jitsuyama Y., Ichiyama K., Sugiura E., Yudate T., Nakamura S., Gopal J. 2012. Effect of interseeding cover crops and fertilization on weed suppression under an organic and rotational cropping system. 1. Stability of weed suppression over years and main crops of potato, maize and soybean. Field Crop Research, 127: 9-16

http://dx.doi.org/10.1016/j.fcr.2011.10.007

Vakali C., Zaller J. G., Köpke U. 2011. Reduced tillage effects on soil properties and growth of cereals and associated weeds under organic farming. Soil and Tillage Research, 111: $133-141$

http://dx.doi.org/10.1016/j.still.2010.09.003

ISSN 1392-3196 / e-ISSN 2335-8947

Zemdirbyste-Agriculture, vol. 102, No. 4 (2015), p. 363-370

DOI 10.13080/z-a.2015.102.046

\section{Kukurūzų ir piktžolių sąveika ilgalaikio supaprastinto žemès dirbimo sąlygomis}

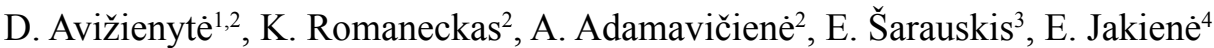

${ }^{1}$ Lietuvos agrarinių ir miškų mokslų centro Rumokų bandymų stotis

${ }^{2}$ Aleksandro Stulginskio universiteto Agroekosistemų ir dirvožemio mokslų institutas

${ }^{3}$ Aleksandro Stulginskio universiteto Žemès ūkio inžinerijos ir saugos institutas

${ }^{4}$ Aleksandro Stulginskio universiteto Žemès ūkio ir maisto mokslų institutas

\section{Santrauka}

Taikant supaprastintą žemės dirbimą arba sèją į neįdirbtą ražieną, viena svarbiausių problemų yra didèjantis pasèlių piktžolėtumas. Tyrimo tikslas - taikant šias technologijas nustatyti sąveiką tarp kukurūzų ir piktžolių, nes nėra pakankamai tyrimų duomenų iš Baltijos pietinio regiono, kuriame vyrauja tarpinis kontinentinis-jūrinis klimatas.

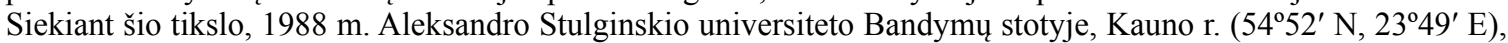
buvo pradètas vykdyti stacionarus supaprastinto žemės dirbimo lauko eksperimentas. Dirva rudenį buvo arta $22-$ $25 \mathrm{~cm}$ (kontrolinis variantas) ir 12-15 cm gyliais, giliai $(25-30 \mathrm{~cm})$ ir sekliai $(10-12 \mathrm{~cm})$ purenta ir visai nedirbta. Giliai ir sekliai purentuose ar nedirbtuose laukeliuose žieminių kviečių liekanos dengė 5,9, 5,7 ir 13,2 karto didesni dirvos paviršiaus plotą nei kontrolinio. Kukurūzų pasėlio 1/4, 1/2 ir 3/4 aukščio arduose apšvita dažniausiai buvo didesnè taikant supaprastintą žemès dirbimą ir nedirbtos dirvos sąlygomis nei ją suarus. Be to, piktžolių sẻklų dirvožemio viršutiniame $(0-15 \mathrm{~cm})$ sluoksnyje buvo rasta 60 proc. daugiau nei gilesniame $(15-25 \mathrm{~cm})-40$ proc. Nustatyta, kad daugiamečių piktžolių giliai ir sekliai purentuose laukeliuose buvo 2 ir 3 kartus daugiau nei tradiciškai artuose. Kukurūzų vegetacijos pabaigoje minimaliai ịdirbtuose ar nedirbtuose laukeliuose, palyginus su giliai artais, buvo atitinkamai 46, 40, 30 ir 16 proc. didesnis skaičius piktžolių, o jų sausoji biomasẻ buvo 30, 22, 36 ir 17 proc. mažesnè.

Piktžolių išplitimas trumpos vegetacijos kukurūzuose labiausiai priklausė nuo dirvos paviršiaus padengimo augalinėmis liekanomis, kukurūzų pasẻlio tankumo ir aukščio bei apšvitos sąlygų.

Reikšminiai žodžiai: augalinės liekanos, pasėlio apšvita, piktžolių sẻklų kiekis dirvoje, piktžolių skaičius ir biomasè, Zea mays. 